\title{
Incidence of sperm antibodies before and after vasectomy
}

\author{
J. HUNTER, H. LOGAN, AND G. GREER
}

From The Ulster Hospital, Dundonald, Belfast

SYNOPSIS Sperm-agglutinating antibodies were present in three $(2.6 \%)$ of 117 fertile men and in 19 $(33.9 \%)$ of 56 men who had been vasectomized. Twenty-four of the 56 vasectomized men had been studied before vasectomy; sperm-agglutinating antibodies were present in one (4.3\%) compared with eight $(33.3 \%)$ after vasectomy. No sperm-immobilizing antibodies were detected before vasectomy but were present in $10(17.9 \%)$ of the 56 men after vasectomy.

The presence of sperm-agglutinating antibodies in the serum of four infertile men with oligozoospermia (Rümke, 1954; Wilson, 1954) focused attention on the presence of such antibodies in patients with proven obstruction of the vasa deferentia and also after bilateral vasectomy (Phadke and Padukone, 1964). Subsequently an increased level of complement-dependent sperm-immobilizing antibodies in addition to sperm-agglutinating antibodies was detected in men after bilateral vasectomy for contraceptive reasons (Ansbacher et al, 1972; Shulman et al, 1972; Halim and Antoniou, 1973).

This paper is a study of the incidence of sperm antibodies in fertile men and in vasectomized men.

\section{Patients}

Blood samples were collected from 117 men on referral for vasectomy and from 24 of them between

Received for publication 30 April 1976 one and three years after vasectomy. Samples were also taken from a further 32 men who had been vasectomized between one and three years previously but who had not been tested before vasectomy.

\section{Methods}

The sera obtained from the blood specimens were tested for the presence of sperm-agglutinating antibodies using the macroscopic sperm-agglutination test of Kibrick et al (1952) starting with a 1:4 dilution, and for the presence of sperm-immobilizing antibodies using the method described by Isojima and Ashitaka (1968) starting with a 1:2 dilution.

\section{Results}

The results are shown in the table. Three $(2.5 \%)$ of the 117 men referred for vasectomy had agglutinating antibodies in their serum in a titre of $1: 4$ or greater, but no immobilizing antibodies were detected. In the

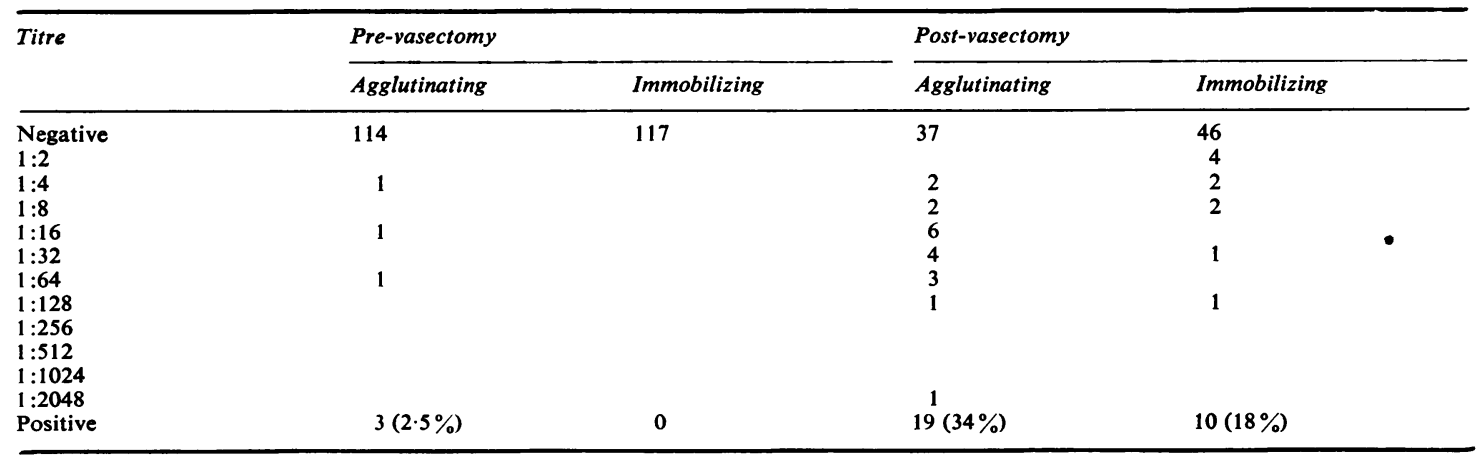

Table Sperm antibodies in 117 men before vasectomy and in 56 men after vasectomy 
56 men studied after vasectomy, sperm-agglutinating antibodies were detected in $19(34 \%)$ and spermimmobilizing antibodies in $10(18 \%)$.

Twenty-four men included in the overall results were studied both before and after vasectomy. The incidence of sperm-agglutinating antibodies increased from one $(4.5 \%)$ before vasectomy to eight $(33.5 \%)$ after vasectomy. Sperm-immobilizing antibodies were detected in three $(12.5 \%)$ after vasectomy whereas none had been detected before operation.

\section{Discussion}

These studies support the view that there is a background of sperm-agglutinating antibody activity in fertile men and that this activity increases after bilateral vasectomy (Ansbacher et al, 1972; Shulman et al, 1972; Halim and Antoniou, 1973).

While it is agreed that a level of sperm-agglutinating antibody in men is compatible with fertility, it has not been possible to establish a threshold of significance. Rümke and Hellinga (1959) found agglutinating antibodies in four of $\mathbf{4 1 6}$ fertile men in titres ranging from 1:4 to $1: 16$. Two of 100 fertile men studied by Halim and Antoniou (1973) had sperm-agglutinating antibodies to a titre of $1: 32$, and one of the 117 fertile men whom we studied had sperm-agglutinating antibodies to a titre of $1: 64$. The Kibrick method was used in all of these studies.

The extent of the reported increase in the level of sperm-agglutinating antibody activity after vasectomy varies in different studies. Halim and Antoniou (1973), considering levels of 1:32 or greater to be significant, found antibody titres of $1: 32$ in two of 100 men before vasectomy and in six of these 100 men after vasectomy. Shulman et al (1972), considering a titre of $1: 8$ to be positive, found significant increase in sperm-agglutinating activity on at least one occasion after surgery in 12 of their 22 patients. In their study of 27 cases, Ansbacher et al (1972) reported antibodies to a titre of $1: 4$ in one before vasectomy and in 12 in titres ranging from $1: 2$ to 1:1024 after vasectomy. In the 24 men studied both before and after vasectomy, we found spermagglutinating antibodies in one before vasectomy in a titre of 1:64. After vasectomy this was found to be $1: 128$, the rise being of doubtful significance. However, a-further seven patients were found to have sperm-agglutinating antibodies after vasectomy in titres ranging from 1:8 to $1: 64$.

Antibody levels may depend on the time that has elapsed since vasectomy. Ansbacher et al (1972) found an increase in sperm-agglutinating antibody titres at six and 12 months compared with six weeks, indicating continued antigenic stimulation. Shulman et al (1972) studied the antibody titres at regular intervals after vasectomy in seven patients. They found two types of response. In four of their seven patients, there was a peak between the second and sixth months after operation, followed by a decline, whereas in the other three there was a later response beginning about the fifth or sixth month. All our patients were tested between one and three years after vasectomy.

Halim and Antoniou (1973) also found a back- $\overrightarrow{0}$ ground of sperm-immobilizing activity in fertile $\vec{\overrightarrow{ }}$ men which increased after vasectomy, but, as in the 27 men investigated by Ansbacher et al (1972), we 응 found no such activity before vasectomy. We did, however, find sperm-immobilizing antibody activity in three $(12.5 \%)$ of the 24 men after vasectomy, in $\vec{N}$ whom none had been detected before operation, and overall in $10(18 \%)$ of the 56 vasectomized men in- $\vec{v}$ vestigated.

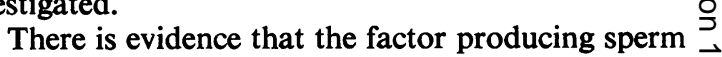
agglutination and immobilization is an antibody. Rümke and Hellinga (1959), using paper electrophoresis, found the agglutinating activity in the $\gamma-\frac{\Phi}{3}$ globulin fraction. Later Quinlivan et al (1975) found ${ }_{\mathbb{\Phi}}$ that immoglobulin $\mathrm{G}$ obtained from the sera of men with agglutinating or immobilizing activity b\& $\overrightarrow{0}$ column chromatography produced the same effect as whole sera.

The significance of these antibodies is not knownt The fact that more sterile men than fertile men have antibodies in their sera (Rümke and Hellinga, 1959; Halim and Antoniou, 1973) suggests an association with infertility. However, there is evidence that $\overrightarrow{\vec{P}}$ obstruction of the vasa may result in the formation of antibodies, and it cannot be concluded that the antibodies rendered the men sterile (Rümke and Hellinga, 1959).

In the case of antibodies appearing after vasectomy, one possible consequence is infertility persisting after reanastomosis of the vasa. This is not supported by Phadke and Padukone (1964), who reported that in six patients in whom obstructive azoospermia was corrected by vaso-epididymal 윽 anastomosis, three subsequently proved fertile $\rightarrow$ despite having high titres of sperm agglutinins.

Further evidence is clearly required to establish a $N$ possible relationship between the sperm antibodies which appear in vasectomized men and their subsequent infertility after reanastomosis of their vasa.

References

Ansbacher, R., Keung-Yeung, K., and Wurster, J. C. (1972). Sperm antibodies in vasectomised men. Fertil. and Steril., 23, 640-643.

Halim, A. and Antoniou, D. (1973). Autoantibodies to 0 spermatozoa in relation to male infertility and vasectomy. Brit. J. Urol., 45, 559-562. 
Isojima, S., Li, T. S., and Ashitaka, Y. (1968). Immunologic analysis of sperm-immobilizing factor found in sera of women with unexplained sterility. Amer. J. Obstet. Gynec., 101, 677-683.

Kibrick, S., Belding, D. L., and Merrill, B. (1952). Methods for the detection of antibodies against mammalian spermatozoa. II. A gelatin agglutination test. Fertil. and Steril., 3, 430-438.

Phadke, A. M. and Padukone, K. (1964). Presence and significance of autoantibodies against spermatozoa in the blood of men with obstructed vas deferens. J. Reprod. Fertil., 7, 163-170.

Quinlivan, W. L. G., Sullivan, H., and Olsher, N. (1975).
Circulating antispermatozoa immunoglobulin $G$ in men after vasectomy. Fertil. and Steril., 26, 224-227.

Rümke, P. (1954). The presence of sperm antibodies in the serum of two patients with oligozoospermia. Vox Sang (Amst.), 4, 135-140.

Rümke, P. and Hellinga, G. (1959). Autoantibodies against spermatozoa in sterile men. Amer. J. clin. Path., 32, 357 363.

Shulman, S., Zappi, E., Ahmed, U. A., and Davis, J. E. (1972). Immunologic consequences of vasectomy. Contraception, 5, 269-278.

Wilson, L. (1954). Sperm agglutinins in human semen and blood. Proc. Soc. exp. Biol. (N.Y.), 85, 652-655.

\section{The November 1976 Issue}

\section{THE NOVEMBER 1976 ISSUE CONTAINS THE FOLLOWING PAPERS}

Adenosquamous carcinoma of the endometrium M. T. HAQQANI AND H. FOX

A case of primary lymphoma of the liver T. J. CHAMBERS, D. P. O'DONOGHUE, AND A. G. STANSFELD

Factor VII as a marker of hepatocellular synthetic function in liver disease G. GREEN, L. POLLER, JEAN M. THOMSON, AND I. W. DYMOCK

An interpretation of the serum alkaline phosphatase isoenzyme patterns in patients with obstructive liver disease C. P. PRICE AND H. G. SAMMONS

Biochemical indices of osteomalacia in pregnant Asian immigrants in Britain A. T. HOWARTH

Clinical and immunochemical study of the serum IgG fraction not precipitated in a zinc-sodium salicylate reagent JACQUES BADIN AND MARIE-ANNICK DENNE

Improved antibody detection by the use of range expansion and longer filter wavelength in a low ionic strength-protamine sulphate AutoAnalyzer system D. M. DOWNIE AND D. VOAK

Removal of non-specific serum inhibitors of haemagglutination of rubella virus by treatment with dodecylamine-gel W. K. K. HO AND K. F. SHORTRIDGE

Staphylococcal protein $\mathbf{A}$; its preparation and an application to rubella serology $H$. MALLINSON, C. ROBERTS, AND G. B. BRUCE WHITE
Abnormal responses to rubella infection D. J. JEFFRIES, ANTHEA H. JOHNSON, AND J. F. MOWBRAY

Indirect immunofluorescence assay for antibody to germ tube of Candida albicans - a new diagnostic test Y. M. HO, M. H. NG, C. H. TEOH-CHAN, P. C. K. YUE, AND C. T. HUANG

Characteristics of a strain of Clostridium carnis causing septicaemia in a young infant A. J. WORT AND R. L. OZERE

Marine vibrios associated with superficial septic lesions w. J. RYAN

Symposium: Malignancy in childhood

Morphology and incidence of childhood tumours H. B. MARSDEN

Teratomas and yolk-sac tumours N. J. BROWN

Clinicopathological role of tumour index substances in paediatric neoplasia A. MUNRO NEVILLE, $K$. GRIGOR, AND E. HEYDERMAN

Aetiological factors in childhood neoplasia C. L. BERRY

\section{Technical method}

Simplified qualitative chemical analysis for urinary calculi J. KLEEBERG

Letter to the Editor

Book : eviews

The Association of Clinical Pathologists: 96th general meeting

Copies are still available and may be obtained from the PUBLISHING MANAGER, BRITISH MEDICAL ASSOCIATION, TAVISTOCK SQUARE, LONDON, WC1H 9JR, price $£ 2.00$, including postage 